\title{
So much for Bardolatry! (Drunken) Romeo and Juliet in Shit-faced Shakespeare
}

by Dan Mills. Published in 2019 Issue 1.

For the production: Romeo and Juliet (2019, Magnificent Bastard Productions, Village Theatre). Date performance attended: 2019-6-22. See production details at the end of the review.

At the Village Theatre in downtown Atlanta, Magnificent Bastard Productions recently staged their version of "Shit-faced Shakespeare." An import from the UK that now also appears in Austin, Pittsburg, Boston, and Australia, Shit-faced Shakespeare provides an hour-long, significantly condensed version of one of Shakespeare's plays in which one of the actors has consumed a considerable amount of alcohol before the performance. The remaining performers attempt to stage the stripped-down version of the play while improvising responses and adjustments based on the drunken performer's antics. The show provided an hour of good dirty fun and highlighted the populist nature of American Shakespearean appropriation and commodification and the intersection of highbrow and lowbrow culture in American society. The final section of this review explores these aspects of Shakespearean appropriation through engagement with the writings of Antonin Artaud, Guy Debord, and Lawrence Levine on the theatre of cruelty, the society of the spectacle, and highbrow and lowbrow culture, respectively.

Shit-faced Shakespeare has created versions of several of Shakespeare's plays, including Hamlet, Macbeth, and A Midsummer Night's Dream. On the night this reviewer attended, the Village Theatre presented the "shit-faced" version of Romeo and Juliet, in which the actor playing Romeo (Robert Hindsman) was the designated shit-faced performer. There were laughs aplenty and the show would be a delight for people with any level of familiarity with Shakespeare, Romeo and Juliet, or the theatre in general, including those who were "supposed to read" the play in high school.

The auditorium sat a few hundred people in front of a thrust stage, with the show selling out several days before its presentation. Before the performance began, loud contemporary pop music blasted through the space. The audience was a diverse mix of ages and ethnicities, and some members looked and acted like they attended the performance to do their pre-drinking prior to going out to Atlanta's night clubs to get really shit-faced. Before the performance began, Rachel Frawley as Compere (master of ceremonies), dressed like a cross between a zombie showgirl and Dr. Frank-N-Furter from The Rocky Horror Picture Show, introduced the concept of the performance and handed out "toys" - including a small cymbal and mallet and a brass hornthat the audience members were supposed to sound when they wanted drunken Romeo to drink 
even more. As the Compere told the audience, Romeo had already single-handedly consumed more than half a liter of handmade Vodka. While Frawley's Compere explained the rules of the show, she stood by a rolling bar stand on which sat a bucket of bottled Yuengling, the US's topselling craft mega-beer. Perhaps more expensive American-style IPAs, like the ones sold in the trendy shop in the same building, were not appropriate to get our fearless lover hero shit-faced, and it makes sense that the drink of choice was a domestic beer in light of the populist nature of this show.

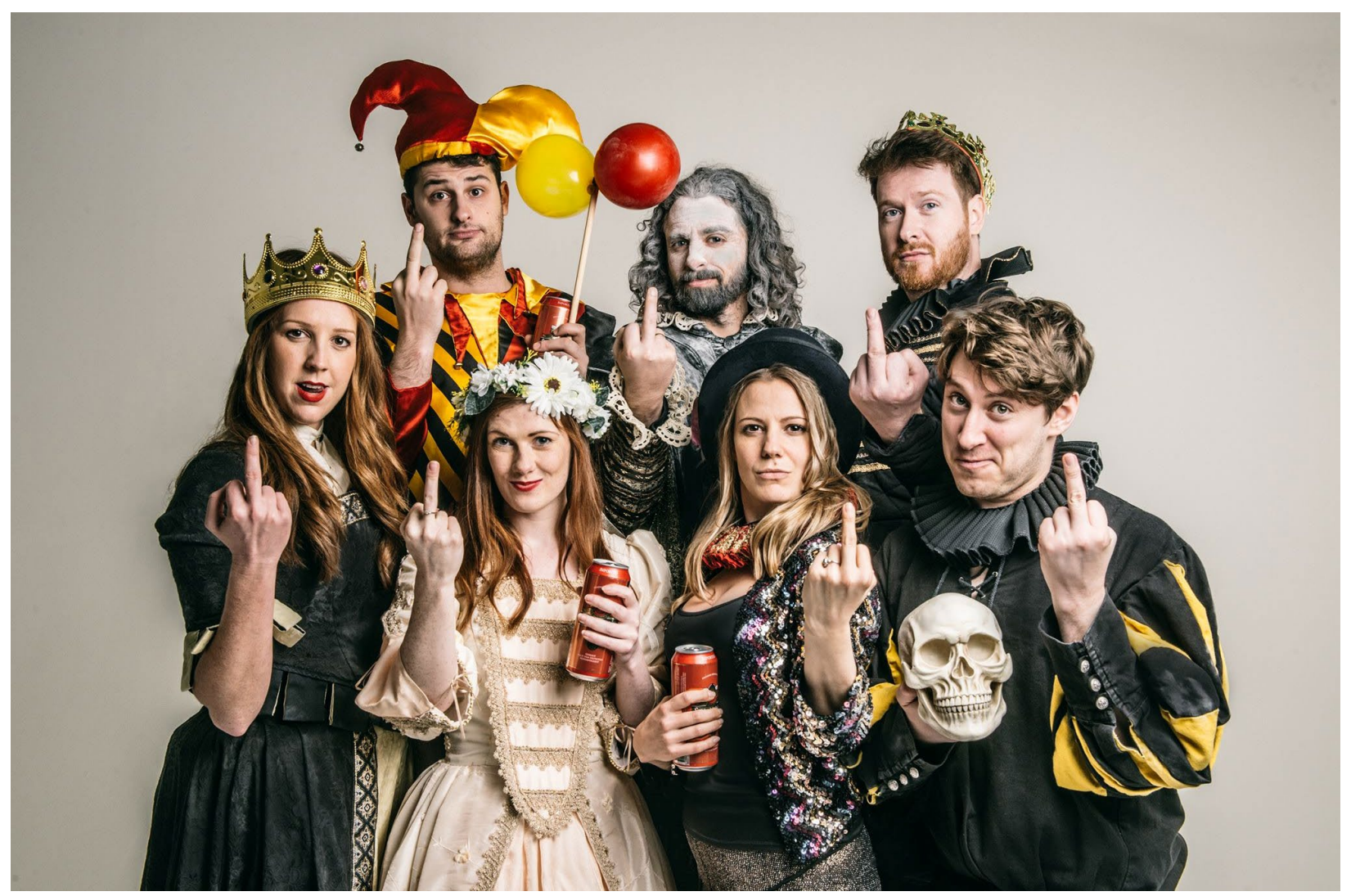

Figure 1. The cast of Shit-Faced Shakespeare US. Photo credit: Rah Petherbridge Photography.

The performance involved a considerable amount of audience interaction and fourth-wall breaking, as the stage did not extend very far into the seating space and the first row sat very close to the forestage. Fourth-wall breaking included the drunken Romeo telling the audience to "fuck off," Romeo giving us the middle finger, and an audience member being called onto the stage to play Paris, and then telling the crowd he was known for having a "big domain." At one point, drunken Romeo made a comment to a rowdy front-row audience member about wearing a red "Make America Great Again" hat, suggesting he was a supporter of President Donald Trump's 2016 campaign promises. "It's not a MAGA hat!" the playgoer and his party yelled, to which Romeo replied by slurring that it was dangerous to wear any red hat in Atlanta. The audience's 
responding cheer highlighted the city's left-leaning political disposition, despite being the capital city of a largely Republican-voting state.

As the red-hat episode demonstrates, the audience seemed to enjoy the improvised comedic parts of the performance much more than the relatively sparse use of lines from Shakespeare's play, which is, perhaps, only to be expected given contemporary educational attitudes to classic texts. Consequently, the Village Theatre's Shit-faced Shakespeare production elicited an antiintellectual reaction from the audience that reflects a similar trend in American secondary and post-secondary schools. The fact that Shit-faced Shakespeare hails from the UK might be considered ironic in this light, since American observers often erroneously believe Shakespeare garners more reverence in his home nation than in the United States. Despite first being formed in 2010 as an apparent backlash to economic downturn and austerity worldwide, Shit-faced Shakespeare appears particularly relevant in the wake of both the Brexit referendum for Great Britain to leave the European Union, and the election of Donald Trump in the US, two highly controversial populist political developments. It is not difficult to suggest how and why Magnificent Bastard Productions has found and filled its international niche potential, especially in a very turbulent time for two of the most populous English-speaking countries.

Worldwide political turbulence aside, the drunken ramblings of shit-faced Romeo were interspersed with a few lines from the actual play, an effect that was, for anyone versed in Shakespeare, rather jarring. The direct quotes from Romeo and Juliet that did appear seemed chosen to merely advance the plot, while many had some level of sexual innuendo. This observation should not be read as a complaint at the desecration of a Shakespearean tragedy, as that was the very point of the show and Shakespeare's plays are certainly not without their fill of dirty jokes. In fact, these textual references allowed the audience to see, in some form or another, many highlights from the play, including the dueling death

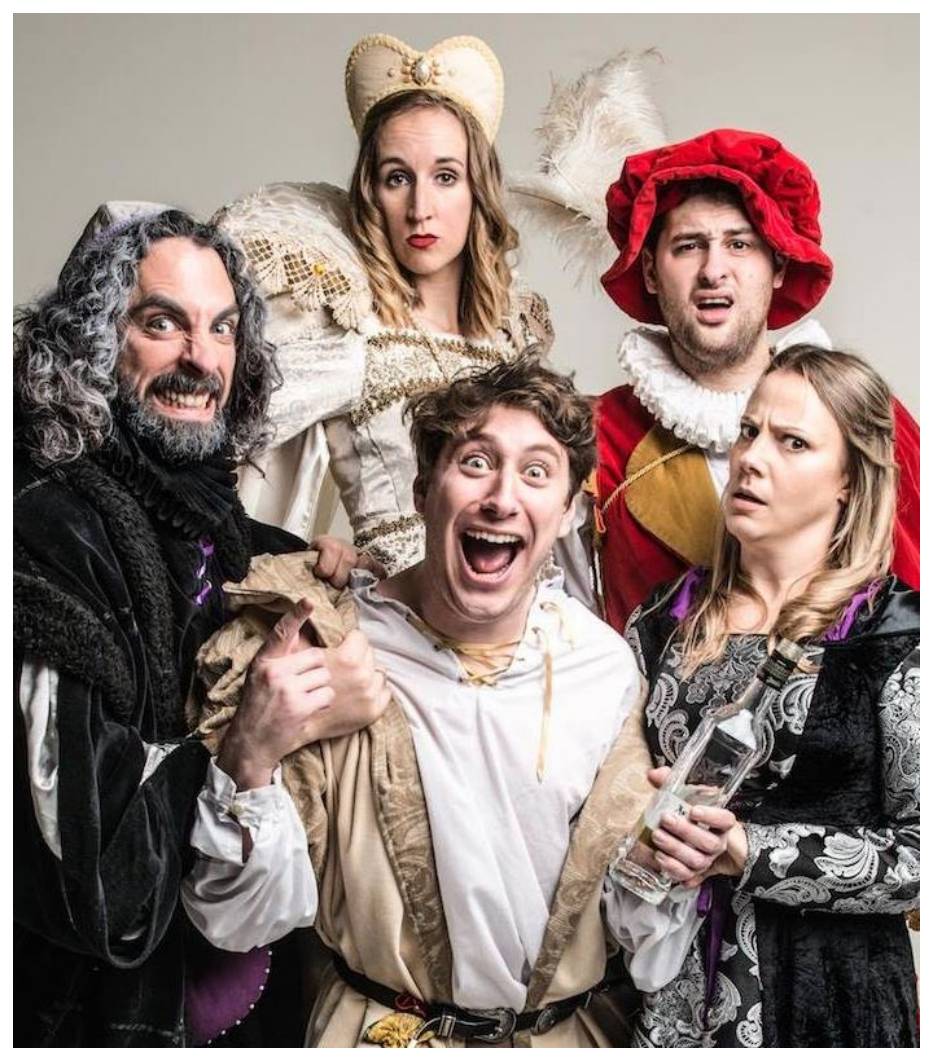

Figure 2. Shit-faced Shakespeare's Romeo and Juliet cast. Photo credit: Rah Petherbridge Photography. 
that leads to Romeo's banishment, the visit to the apothecary, and the confusing death-rebirthdeath of Juliet in the play's final act. The audience seemed, however, more interested in and were more entertained by the off-script drunken ad-libs of Romeo than the few passages from the actual play. Although such improvisations seemed slightly scripted-live improv is never entirely improvised-it is worth appreciating the difficulty of having to reproduce an inherently random and potentially chaotic performance piece, which only makes Hindsman's Romeo ad-libbing more impressive.

While Romeo was given free rein to act the comic fool, the non-drunken actors played the roles of "straight men" to his drunken antics with what seemed like a solid knowledge of Shakespeare's play, all performing this Herculean task with gusto. Despite a lot of doubling, the costumes and character shifts in performance kept things relatively easy to follow. Katie Causey played the Nurse and a feminized version of Benvolio ("Benvolia"), Ben Barlow played Mercutio and Friar Laurence, and David Sterritt played Tybalt and Capulet. Costume alterations aside, for both of Barlow's roles, the actor wore a stuffed cloth codpiece that looked more like a large red penis than a fashion accessory, a choice suited to Mercutio but anarchically incongruous on the friar. Although the doubling became even more confusing in the play's second half, it was still relatively clear who was doing what, with which, and to whom.

If confusion, improvisation, and prosthetic penis codpieces added their unique style to Shitfaced Shakespeare's Atlantan venture, the theatre venue itself suggested an alternative anarchic potential to a production that seemed, by its very nature, to shout "fuck off" to the Shakespeare establishment. The Village Theatre is walking distance from Georgia State University, past home to professor emeritus James Hirsh, whose scholarly work on soliloquies might be considered more traditional or reverent toward Shakespeare. Although most likely unconscious on the part of the production company and the venue, especially as US universities often have the most accessible theatre spaces and a ready audience of young, informed, and potentially irreverent customers, this proximity to seriously taught Shakespeare courses made the performance seem like a cruel yet very entertaining joke for anyone familiar with the Shakespeare academy. This reviewer, for instance, was reminded of French dramatist and theatre director Antonin Artaud's 1930s Le Théâtre et son Double (The Theater and its Double), in which Artaud describes his proposition for a "theater of cruelty" (Artaud 1938, 86). The aim of Artaud's theatre of cruelty is "to attack the spectator's sensibility on all sides," by means of a "revolving spectacle which, instead of making the stage and auditorium two closed worlds, without possible communication, spreads its visual and sonorous outbursts over the entire mass of the spectators" (Artaud 1938, 86). Artaud is of course referring to the disintegration of the fourth wall in the theatre space, which Shakespeareans will recognize as the norm for early modern and contemporary "Globe"-style 
performances, while also implying the emancipatory and even revolutionary goals of his theatre of cruelty. Artaud suggests that the "mass" of spectators, traditionally associated with those stinkard groundlings who, as Hamlet contends, are "capable of nothing but inexplicable dumbshows and noise," need to be bombarded with spectacle to become motivated. Artaud's vision, it seems, precisely describes the theatregoer's experience at Shit-faced Shakespeare, some in the audience being themselves rather shit-faced after being encouraged to become so by certain performers. Again, like the groundlings who interact with the onstage actors, the Shit-faced Shakespeare spectators were part of the spectacle. Unlike traditional Shakespearean theatre production and scholarship, the show also perpetrated a rather cruel assault on Shakespeare through its drunken, populist, iconoclastic riff on Romeo and Juliet.

Even though Shit-faced Shakespeare is merely representative of how English-speaking culture and non-English global appropriations are continuously and predictably decanonizing Shakespeare's plays, this production shows how Magnificent Bastard Productions has found an alternative commodification for Shakespeare: by marketing their shows to a broader audience, some of whom are less likely to sit through a three-hour performance of a traditional Shakespearean drama but who are attracted to the irreverence of the play's title and conceit. The entire experience was indeed a semiotically "revolving spectacle," to use Artaud's words, that welcomed interactivity between audience and actor, while negating any sense of high cultural distance and voyeuristic reserve. Indeed, the production highlighted the difference between audience as auditor and audience as spectator and participant in quite remarkable ways. This reviewer was therefore reminded how, in La sociéte du spectacle (Society of the Spectacle), French Marxist philosopher Guy Debord writes that the "spectacle is not a collection of images; rather, it is a social relationship between people that is mediated by images" (Debord 1967, 12). Images in this performance included the hyperbolic codpiece and a makeshift bed on which shit-faced Romeo and stone-cold sober Juliet (Destiny Thompson) frolicked and made out, as well as the occasional intervention of the zombie showgirl Compere who provided the beer that Romeo had to drink to become more intoxicated. Believing that the spectacle's "externality" as an "acting subject" transforms the individual into an automaton controlled by someone else, Debord sees this social puppetry as leading to the individual's own alienation in the midst of a spectacle that surrounds them (Debord 1967, 23). Such defamiliarization precisely characterizes this alienated experience, as most people have either read Romeo and Juliet or at least know the basic plot premise of the play. This production provided the play's greatest hits in an irreverent and campy manner, as Shakespeare's language and gestures were appropriated and replaced from the very beginning of the performance, and anyone versed in Shakespearean drama or scholarship was left feeling alienated in the midst of this populist spectacle unless willing to embrace the humor of its irreverent appeal. 
Through the decanonization at the heart of their production, shit-faced Shakespeare presents a violent clash of highbrow and lowbrow culture that is reminiscent of 1980s' cultural commentary by Lawrence Levine, whose Foucauldian-inspired work accords with the new historicist approach that impacted so much late-twentieth century Shakespearean study. Although somewhat outdated, Levine's 1988 Highbrow/Lowbrow: The Emergence of Cultural Hierarchy in America-which states that because ideologies under the control of modification and transformation have produced our

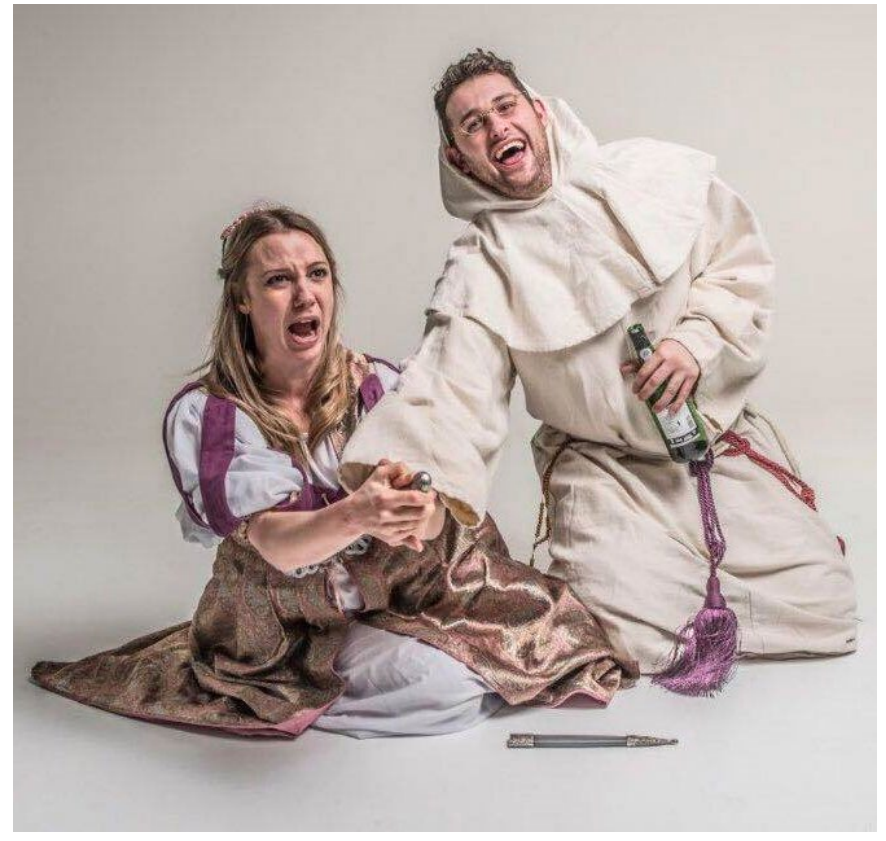

Figure 3. Destiny Thompson as Juliet with Ben Barlow as Friar Laurence. Photo credit: Rah Petherbridge Photography. cultural categories, cultural stratification itself has always been in flux-argues for an inevitable departure from cultural images that Americans have been taught to accept (Levine 1988, 8). Levine's comments about the protean nature of cultural stratification, whereby Derridean modification and transformation make cultural categorization a constantly shifting shoreline, seem particularly applicable to Shit-faced Shakespeare. Levine's description of nineteenthcentury American appropriations of Shakespeare, whereby such "afterpieces and divertissements" [emphasis his] were viewed by contemporary critics as diluting and denigrating the playwright's Bardolatrous status, are countered by Levine's argument that these appropriations should, instead, be hailed for integrating Shakespeare into American culture (Levine 1988, 23). Because nineteenth-century American theatre presented Shakespeare, Levine argues, within "the same milieu inhabited by magicians, dancers, singers, acrobats, minstrels, and comics," the playwright was fully embraced by Americans as culturally their own. Like Shakespeare in nineteenth-century America, Shit-faced Shakespeare mingles the high and the low, the abject and the sublime, to completely relegate the play to such an afterpiece and divertissement. At only an hour long, Shit-faced Shakespeare indeed provides a mere diversion that shares little in common with productions at Shakespeare's more established Georgian home, Atlanta's Shakespeare Tavern, which stages more traditional, full-length productions of Shakespeare's plays, albeit with their fair share of music, comedy, alcoholic beverage consumption, and actively encouraged audience participation. 
The Village Theatre, by contrast, is known primarily for improv, so Shit-faced Shakespeare is a logical path into early modern drama, and perhaps the theatre's regulars had the right mindset to make this performance a success. Although the improv elements of the performance appeared vaguely scripted, such as Benvolia and Juliet's marriage at the end seeming like a foregone conclusion in spite of the ostensibly improvised nature of the divergences from the original play, all of it worked well for what it was supposed to be: an entertaining and fun evening. As we left the theatre after the performance, we heard over the PA that there would be a second performance later that night. Perhaps that performance would be called "Even-more-shit-faced Shakespeare," but it would likely share an uncanny resemblance with the first "improvised" show. Nevertheless, it would definitely be worthwhile to see if the Shit-faced version of A Midsummer Night's Dream has a shit-faced Bottom.

\section{References}

Artaud, Antonin. The Theater and Its Double. Translated by Mary Caroline Richards, Grove Press, 1958.

Debord, Guy. The Society of the Spectacle. Translated by Donald Nicholson-Smith, Zone Books, 2002.

Levine, Lawrence W. Highbrow/Lowbrow: The Emergence of Cultural Hierarchy in America. Harvard University Press, 1988.

\section{Links}

Magnificent Bastard Productions:

https://www.facebook.com/MagnificentBastardProductions/

Shit-faced Shakespeare, USA: http://www.shitfacedshakespeare.com/home

Village Theatre, Atlanta, GA: http://villagecomedy.com/ 


\section{Production Details}

\section{General}

Title

Year

Theater Company

Theater

Start Date

\section{Cast}

BENVOLIA/NURSE

Mercutio/Friar LaURENCE

Tybalt/CAPulet

ROMEO

JULIET

COMPERE

\section{Creatives}

DIRECTOR

Production MANAger

Costume Designer

LIGHTING DESIGNER

SET DESIGN

CHOREOGRAPHY

FIGHT CHOREOGRAPHY

SOUND DESIGNER
Shit-faced Shakespeare: Romeo and Juliet

2019

Magnificent Bastard Productions Ltd.

Village Theatre, Atlanta, GA

2019-06-22

\author{
Katie CAUSEY \\ BEN BARLOW \\ DAVID STERRITT \\ ROBERT HINDSMAN \\ DESTINY THOMPSON \\ RACHEL FRAWLEY
}

